UNIVERSIDAD DE GRANADA

FACULTAD DE FILOSOFÍA Y LETRAS

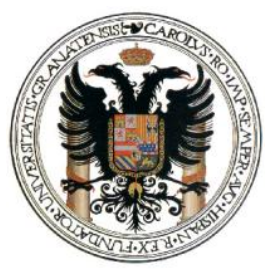

\title{
The beast within: Animalization in Angela Carter's and Carmel Bird's Revisions of "Little Red Riding Hood"
}

\author{
Katarzyna Wielgus \\ Prof. Gerardo Rodríguez Salas (supervisor) \\ University of Granada \\ Máster Universitario en Lingüística y Literatura Inglesas \\ MA. in English Linguistics and Literature
}

$$
\text { June, } 2014
$$




\section{Acknowledgments}

This MA dissertation would not have been possible without the help of my supervisor, Professor Gerardo Rodríguez Salas: my most sincere thanks for his expert academic guidance, dedication, advice, inspiration, and encouragement. I would not have survived this dissertation without his stimulating comments and quick responses to my endless e-mails. For me, he is an example to follow in terms of dedication to his students and his field of research.

Financial support for part of this project was provided by a research grant from the University of Granada, Spain: Beca de Iniciación del Plan Propio de Investigación (2012-2014) de la Universidad de Granada (Vicerrectorado de Política Científica e Investigación). I am grateful for having been given this opportunity.

Lastly, I would like to thank my friends and family, who will forever see me as "The Little Red Riding Hood", for all of their support and encouragement. 


\section{Table of Contents}

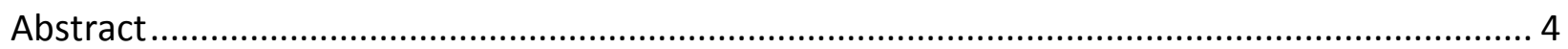

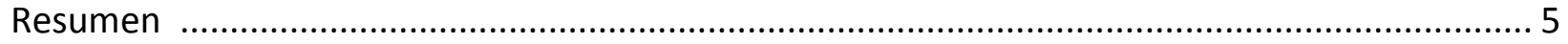

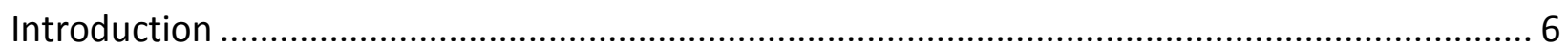

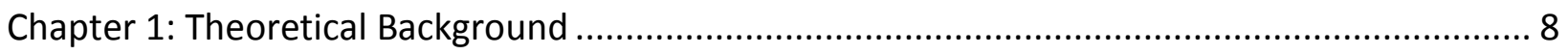

1.1 “Once upon a time”: Red Riding Hood Literary Revisions .............................................. 8

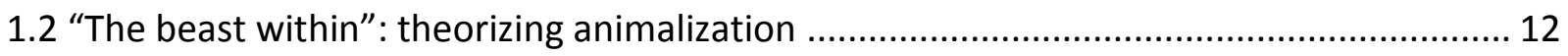

Chapter 2: The "infernal" desires of Angela Carter: "The Company of Wolves" (1979) ............. 24

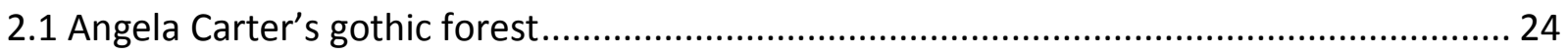

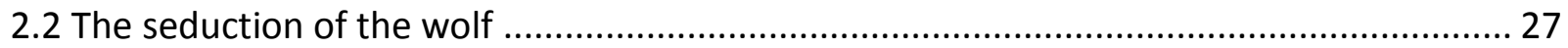

Chapter 3: Fingernails like claws: Carmel Bird's “Cave Amantem” (1985)............................... 35

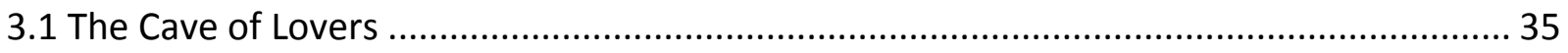

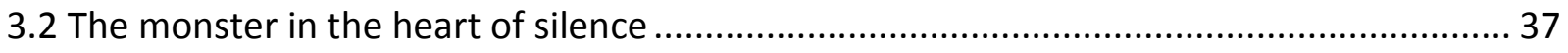

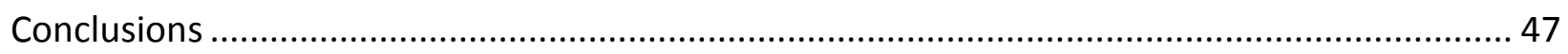

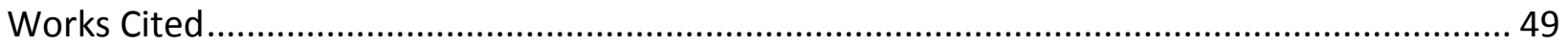




\section{Abstract}

"Little Red Riding Hood", often defined as a "cautionary tale", is the fairy tale which deals exclusively with the body, female sexuality, and the related concepts of morality and the forbidden. This MA thesis investigates the postmodernist gendered revisions of "Little Red Riding Hood" in Angela Carter's "The Company of Wolves" (1979) and Carmel Bird's "Cave Amantem" (1985), and explores the extent to which these texts (de)construct the notions of female sexuality and gender identity and offer different representations and new models for individual and cultural regeneration. This research paper focuses particularly on the subversive strategy of animalization and its connection with corporeity, which has never before been systematically analyzed in connection with the revisions of "Little Red Riding Hood." Given the large disregard of the much wider amalgam of messages on female sexuality and the complexities of identity offered by animalization, the present dissertation will first seek to redefine this technique as a subversive literary strategy. This new liberating vision of animalization will be defended using the theories of feminist and post-colonial critics such as Julia Kristeva, Judith Butler, Rosi Braidotti, Homi K. Bhabha, and Gayatri Spivak, to mention just a few. The more practical component of this thesis will provide a systematic analysis of animalization, understood as the evolutionary exploration of "the beast within" and a powerful tool of female self discovery leading to alternative conceptions of freedom.

KEY WORDS: Fairy tale (re)writing - (post)modern fairy tales - Little Red Riding Hood - female body - corporeity - animalization - sexuality - Carmel Bird - Cave Amantem - Angela Carter Company of Wolves 


\section{Resumen}

"Caperucita Roja", que se ha clasificado como relato aleccionador, es un cuento que está relacionado exclusivamente con el cuerpo, la sexualidad femenina y los conceptos de "lo moral" y "lo prohibido." Esta tesina pretende analizar las versiones de "Caperucita Roja" escritas por Angela Carter y Carmel Bird: "The Company of Wolves" (1979) y "Cave Amantem" (1985) respectivamente. A lo largo del análisis textual se explorará hasta qué punto estas versiones ofrecen una nueva (de)construcción de los conceptos de sexualidad femenina e identidad de género; también se planteará si los relatos cortos analizados ofrecen unas representaciones distintas y modelos novedosos para la regeneración individual y cultural. El presente estudio se centrará sobre todo en la estrategia subversiva de la animalización, cuya conexión con la corporeidad en el contexto de "Caperucita Roja" nunca ha sido analizada de manera sistemática. Dada la falta de reconocimiento de la extensa amalgama de mensajes acerca de la sexualidad femenina ofrecida por la estrategia de animalización, en primer lugar el presente proyecto tratará de reivindicar dicha técnica como una estrategia literaria subversiva. Esta nueva visión liberadora se defenderá partiendo de las teorías de críticos feministas y postcoloniales como Julia Kristeva, Judith Butler, Rosi Braidotti, Homi K. Bhabha, y Gayatri Spivak, entre otros. El componente más práctico de la presente tesina llevará a cabo un análisis sistemático de la animalización, entendida como la exploración evolucionaria de "la bestia interior" y una poderosa herramienta del autoconocimiento femenino que abrirá un camino hacia concepciones alternativas de la libertad.

PALABRAS CLAVE: (re)escritura de cuentos de hadas - cuentos de hadas (post)modernos Caperucita Roja - cuerpo femenino - corporeidad - animalización - sexualidad - Carmel Bird Cave Amantem - Angela Carter - Company of Wolves 


\section{Introduction}

The tale of "Little Red Riding Hood" continues to be told and retold in many countries all over the world. On the surface it is a moralizing, cautionary tale, which warns young girls about the dangers that lurk in the dark forests of life. Yet deep down, it still fascinates with its references to repressed desires and the forbidden present in the story through taboo notions such as female sexuality, sexual initiation, cannibalism and monstrosity. This MA thesis is concerned with the postmodernist gendered revisions of "Little Red Riding Hood" ${ }^{1}$ by Angela Carter and Carmel Bird. The main purpose of this dissertation is to explore the extent to which these versions (de)construct the concept of female sexuality and gender identity and offer different representations and new models for individual and cultural regeneration. The particular focus of this study resides on the subversive strategy of animalization and its connection with corporeity, which has not been systematically analyzed in terms of the revisions of "Little Red Riding Hood." Given the large disregard of the much wider amalgam of messages on female sexuality and the complexities of identity offered by animalization, this dissertation will first seek to redefine this technique as a subversive literary strategy using existing theories. The more practical component of this thesis will provide a systematic analysis of animalization, understood as the evolutionary exploration of "the beast within" and a powerful tool of female self-discovery leading to alternative conceptions of freedom. Accordingly, this thesis has been divided into three chapters in the following way: the first chapter deals with theoretical concerns, while the second and third chapters provide a detailed analysis of animalization using the theoretical rationale introduced in chapter one.

Chapter one will provide some background information on the revisions of traditional fairy tales, as well as the theoretical rationale behind the ambiguous concept of animalization. The

\footnotetext{
${ }^{1}$ The works analyzed could loosely be defined as postmodernist versions of "Little Red Riding Hood" or simply modern fairy tales, though it is important to bear in mind that they do not in fact belong to the fairy tale art, but rather constitute an example of the blurred boundaries of modern literary genres, which in this particular case provide a "creative adaptation of fairy-tale patterns, motifs, and content" (Bacchilega and Roemer, 1998: 7).
} 
theoretical notions discussed will include the concepts of monstrosity, the abject, "the other," the grotesque, mimicry, the female body and sexuality, and gender identity. According to critics such as Mark S. Roberts (2008), any reference to animalization brings to mind racism, colonization, sexism and even genocide. ${ }^{2}$ While acknowledging its negative connotation related to oppression, this paper will focus on animalization purely in the subversive context of sexism. Even in feminist revisions this particular strategy has often been criticized, underestimated and judged to be either a grotesque feminist cliché or a mere pornographic representation of traditional gender roles. Critics such as Patricia Duncker(1984), Avis Lewallen (1988), and Robert Clark(1987) argue that this type of liberated, animalized sexuality within the "straitjacket" of the fairy tale tradition "mimics the set pieces of the pornographic encounter" as they express serious doubts as to the "possibility of a constructive use of pornography" (Benson, 1998: 38). The present study aims to challenge the existing disregard of the strategy of animalization. The principles of Post-structuralism, Postmodernism, and especially Postcolonialism and Feminism provide the background for the analysis of the two selected short stories and for the theoretical subversion of the traditionally negative concept of animalization. Some of the critics cited include Barthes, Lacan, Kristeva, Althusser, Foucault, Said, Bhabha, Spivak, Irigaray, Cixous, Butler, and Braidotti. It will also be necessary to cite experts on the topic of subversion within the fairy tale, such as Jack Zipes, Cristina Bacchilega, and Marina Warner.

Chapters two and three will constitute the project's more practical component, in terms of providing a detailed textual analysis which will apply the theoretical assumptions detailed in chapter one to the specific context of the two short stories. Thus, "The Company of Wolves" (1979) by Angela Carter and "Cave Amantem" (1985) by Carmel Bird will constitute the primary sources used as literary evidence in order to argue the new theoretical definition of the subversive literary strategy of animalization.

\footnotetext{
${ }^{2}$ For a detailed study of animalization as oppression see Mark S. Roberts' The Mark of the Beast: Animality and Human Oppression (2008).
} 


\title{
Chapter 1 \\ Theoretical Background
}

\section{1 “Once upon a time”: Red Riding Hood Literary Revisions}

It was late in the $20^{\text {th }}$ century when the fairy tale ${ }^{3}$ and its inherent connection to myth ${ }^{4}$ became a serious object of literary study. What followed in the last decades of the $20^{\text {th }}$ century and in the $21^{\text {st }}$ century was a critical analysis of the new postmodernist versions of the original tales. Susan Sellers thus comments on the difficult balancing act of the rewriting of myths and fairy tales: "To follow the figure of Little Red Riding Hood and stick to enough of the path so as not to get lost completely, while taking in whatever flowers or strangers we encounter on the way" (2001: 29). She further explains that feminist rewriting can be perceived as both "an act of demolition" and "as a task of construction - of bringing into being enabling alternatives" (Ibid. 30). This vision of postmodernist revisions is shared and further explained by Cristina Bacchilega. She proposes a mirror metaphor in order to illustrate the three phases of fairy tale rewriting: reflection, refraction, and artifice. The first phase, often called mimetic, reflects traditional schemes, the second phase has been termed constructive or refractive since changes are introduced and new alternatives arise, while the last stage is considered to be subversive, as it reveals the artificial ideological construction of traditional tales. ${ }^{5}$ Bacchilega thus explains the three phases of subversive fairy tale rewriting:

\begin{abstract}
Postmodern fictions, then, hold mirrors to the magic mirror of the fairy tale, playing with its framed images out of a desire to multiply its refractions and to expose its artifices. Frames and images may vary, but gender is almost inevitably the privileged place for articulating these de-naturalizing strategies. And while this play of reflection, and framing might produce ideologically "destructive", "constructive" and "subversive" effects, the self-reflexive mirrors themselves are themselves questioned and transformed. (1997: 23-24)
\end{abstract}

\footnotetext{
${ }^{3}$ Fairy tales could be defined as fantasy adventure stories, which take place in an imaginary world: one which is not set in any particular place or time. This is the concept of timeless eternity or illus tempus as defined by Von Franz: "illus tempus, timeless eternity or now and ever" (1982: 16-18, 27).

${ }^{4}$ Susan Sellers analyzes the connection between myth and fairy tale in her 2001 study Myth and Fairy Tale in Contemporary Women's Fiction, especially Chapter One: "Theories of Myth."

${ }^{5}$ The idea of artificial construction of gender roles is prevalent in such critics as Luce Irigaray and Judith Butler and the concept of "performativity."
} 
Possible criticisms about whether a true revolution in thought can be achieved within oppressive patriarchal schemes seem valid issues to be addressed. Stephen Benson voices these concerns in the following way: "Can fairy tales as, traditionally, miniature carriers of a conservative ideology of gender be appropriated to critique, and imagine alternatives to, traditional concepts of gender and its construction, given the history of their role in the installation of these very traditions?" (1998: 37). Two important critics can be cited in defense of the strategy of subversive fairy tale rewritings: Michel Foucault and Julia Kristeva. According to Foucault's theories, ${ }^{6}$ resistance never occurs outside of power; rather, there are numerous points of resistance "present everywhere in the power network" (1990: 95-96). Giving special focus to feminist rewritings, Julia Kristeva points out that any influential revolt must necessarily be understood and thus it has to occur within the hegemonic order of the social-symbolic ${ }^{7}$ (qtd. in Sellers, 2001: 30).

The hidden ideological purpose of fairy tales as instruments for the creation of social structure and order is more than evident (Rodríguez Salas, 2009: 86). More specifically, according to one of the most important fairy tale critics, Jack Zipes, they influenced gender roles and social relations, which were traditionally connected to religion through the concept of morality (Zipes, 1983: 40-42). ${ }^{8}$ In the case of Perrault's version of "Little Red Riding Hood" ${ }^{9}$, the little girl is

\footnotetext{
${ }^{6}$ For more details, see Foucault's theories of power in History of Sexuality or José Medina's 2011 article "Toward a Foucaultian Epistemology of Resistance: Counter-Memory, Epistemic Friction, and Guerrilla Pluralism."

${ }^{7}$ Kristeva's distinction between the Semiotic and the Symbolic is key here; the Semiotic being the pre-linguistic stage associated with women and their silence, and the Symbolic being the linguistic stage associated with men (1986: 133). Kristeva's "strategies for dissident writing" (Sellers, 2001: 30) stand in contrast with the French theories of rejecting patriarchal language and creating a new way of expression for women (Hélène Cixous and l'écriture féminine).

${ }^{8}$ See Jack Zipes's (1983) Fairy Tales and the Art of Subversion. For specific studies on "Little Red Riding Hood" see Zipes's (1993) The Trials and Tribulations of Little Red Riding Hood and Catherine Orenstein's work Little Red Riding Hood Uncloaked: Sex, Morality, and the Evolution of a Fairy Tale (2003).

${ }^{9}$ There are numerous oral versions of this fairy tale, which have been changed in order to "suit the family and educational values of their bourgeois audience" (cf. Bacchilega, 1998: 10). It is impossible in this limited space to even begin to discuss the extent of the editing performed on the original fairy tales or the unacknowledged
} 
clearly portrayed to be a "fallen woman," as she does not fight back the obvious seduction of the wolf (Ibid. 169). She is then eaten by the wolf as punishment for doing what she wanted rather than what was proper and socially accepted. These limitations on female freedom, present in both of the original ${ }^{10}$ versions of the story, sparked a need to distort this traditional vision by the "subversion of the original medium." Subversion could be understood simply as "the departure from the traditional mode" or "greater experimentation" within a given discourse (Zipes, 1983: 107), yet in the light of feminist theories, this strategy could furthermore be said to question the social status quo.

In their short stories, both Angela Carter and Carmel Bird successfully use the marginal discourse and the social and political subversion that characterize Postmodernism. Both tales to be analyzed clearly demonstrate the main characteristics of Postmodernism. ${ }^{11}$ Fragmentation of the narrative as well as constructive ambiguity, which lead to the typically postmodern active involvement of the reader, are evident throughout the short stories. The canonical boundaries

contributions of a group of women in Paris during the 1630's (Ibid.). The oldest widely accepted written text, dating back to the end of the $17^{\text {th }}$ century, belongs to the French author Charles Perrault. In this version the wolf is victorious as the girl is not saved by anyone from her punishment for "straying from the path." In 1812 the other important version of the story is given by the Grimm Brothers, who strove to reinforce Christian aspects, "while deleting sexual references" (Ibid.). A vital change is introduced: the typical happy fairy tale ending is provided as both girl and grandma are saved by a male figure. Perrault's version is the typical "cautionary tale," which is meant to be a warning to girls everywhere. The postmodernist subversive distortion could be regarded to have been more heavily influenced by Perrault's "emphasis on sexual seduction" (Bettelheim, 1989: 176), although the 1812 Brothers Grimm tale is also vital.

${ }^{10}$ It is important to note the distinction between oral folk tales and literary fairy tales, which mixed as they were printed together, and whose origins, especially in the case of oral folk tales, are almost impossible to determine. Another vital concept is the rise of the middle classes in Europe beginning in the $17^{\text {th }}$ century, which brought about the didactic mission of editing tales in accordance with Christian values and "patriarchal attitudes about gender" especially in the $19^{\text {th }}$ century (Zipes, 1983: xi). It goes beyond the scope and purpose of this dissertation to analyze the exclusion of women from the literary canon and the importance of the transformation of the fairy tale from the oral folk tradition to literary versions by male writers, which had clear political and religious agendas. The important role of women in the oral story telling process has been omitted, while the male canonical versions are considered the classics.

${ }^{11}$ I will follow Rodriguez Salas' presentation of postmodernist subversive strategies, as elaborated in his 2009 study, where he takes Ihab Hassan's ideas as a departure point (91-92, 137). 
of traditional texts become blurred, as intertextuality, plurality of forms and the concepts of critical irony, parody and Bakhtin's "carnivalesque" come into play. The novelty, the surprise, or the absurd logic emerges through the distortion of familiar characters, often expressing humoristic or serious critical judgments of the contemporary world (Koch, 2006: 43). The notions of intertextuality and parody evolve into "the general mode of the work itself" in Postmodernism (Rose, 1993: 5-6). The distorted echoes of the original fairy tale help new meanings and criticisms emerge to the surface. As different genres mix and overlap, fantasy reveals a subversive message directed at the real world and a clear attempt at a point of view favorable to traditionally marginal figures is present (Rodríguez Salas, 2009: 23, 30-31). Furthermore, the concept of literature as mimesis is rejected, as reality is constructed through language and the individual is perceived as fiction, following Nietzsche's idea (Ibid. 28). Lastly, the mimetic notion of language as a direct reflection of reality is challenged through Postmodernism's inherent connection with Post-structuralism, as language is deconstructed in order to reveal hegemonic ideologies.

Since the beginning of the $20^{\text {th }}$ century different subversive strategies, which echo these postmodernist characteristics, have been used to distort traditional, strongly patriarchal fairy tales. These gendered revisions of the fairy tale have nowadays become quite commonplace. The fiction of Robert Coover, Tanith Lee, Margaret Atwood, Jeanette Winterson (Benson, 1998: 49), and particularly as in the focus of the present study, of Angela Carter and Carmel Bird constitute the renaissance of the fairy tale which has been going on for the past decades. The many revisions of "Little Red Riding Hood" must somehow be rooted in the numerous oral versions of the traditional folk tale. It goes beyond the scope and purpose of this dissertation to go into any more detail on the transformation of the fairy tale itself, which could be interpreted in terms of feminist theory according to the metaphorical connection between text and body. The fascination with "Little Red Riding Hood" as a body of tales which undergo endless transformations could be interpreted as a feeling of awe and wonder at this monstrous female body in the endless process of reproduction and rewriting. These discussions of the narrative process of fairy tale transmission, as well as criticisms of the concept of one canonical, master 
version and many silenced rewritings considered secondary texts, will have to wait to be discussed in a future PhD thesis. It only remains to be said that the themes related to the forbidden, such as sexuality, monstrosity and cannibalism continue to fascinate modern readers and provide new twists on the tale. Some $20^{\text {th }}$ century revisions include Catherine Storr's 1967 tale of "Little Polly Riding Hood" in which the clever and independent girl outwits the wolf; the 1972 subversive version of the Merseyside Women's Liberation Movement in Liverpool in which the little girl saves her grandmother and kills the wolf; and Tomi Ungerer's 1974 emancipatory rewriting of the story with a happy end where the wolf and the girl marry (Zipes, 1983: 179-180). There are also many versions written in defense of the wolf. These include Iring Fetscher's 1974 "Little Redhead and the Wolf" and Philippe Dumas and Boris Moissard's 1977 "Little Aqua Riding Hood" (Ibid.). Here, it is inevitable to mention the 1992 Bestseller Women Who Run with the Wolves by Clarissa Pinkola Estés. This intercultural collection unfolds myths, fairy tales, and stories of the "wild woman archetype" with fresh perspectives. There is a connection between the traditionally naïve Little Red Riding Hood character and the evil wolf, which restores women's instinctive and intuitive nature. This connection between woman and animal (wolf) constitutes the main assumption behind the subversive strategy of animalization.

\section{2 "The beast within": theorizing animalization}

It was as a comment on human nature that the concept of 'animality' was devised. (Thomas, 1983:41)

Many critics have drawn an analogy between Poststructuralism, Postmodernism, Marxist Criticism, Post-colonial theory, and Feminism. ${ }^{12}$ The fact that the relationship between men and women has so often been compared with that of the imperial power and the colony (Ashcroft, 1989: 30) allows for what could be termed as a "post-patriarchal" interpretation of animalization. It would be an understatement to say that the word itself brings to mind negative connotations, given the fact that it has often been defined as a synonym of degradation, brutalization, and dehumanization, especially in the context of post-colonial

\footnotetext{
${ }^{12}$ Bhabha, Spivak, Morrison, Lessing, Atwood, among others.
} 
theory (c.f. Smelik, 2003: 66). Animalization, or "the rendering non-human of humans," has throughout history been used to justify domination and exploitation of those regarded as "inferior human groups" such as racial and religious minorities and, particularly important from the feminist perspective, women (Roberts, 2008: x). Let us examine a particularly interesting example:

There are large numbers of women whose brains are closer in size to those of gorillas than to the most developed male brains... Without doubt there exist some distinguished women, very superior to the average man, but they are as exceptional as the birth of any monstrosity, as, for example, a gorilla with two heads, consequently we can reject them entirely. (Le Bon qtd. in Roberts: 27. Emphasis added)

Although this is an example of animalization with a clearly sexist agenda, the association of talented women with monstrosity is very curious in terms of our new approach to this traditionally oppressive strategy, given that it could be read subversively taking into account the fact that the animalized images of Little Red Riding Hood in this study are precisely subversive monstrous representations of the female body. I will come back to this point further on. Within animalization, monstrosity, along with bestiality, and the grotesque, and their connection with repressed fears and social taboos, reflect different subversive notions of gender representation. Subversion could loosely be defined as a radical intent to undermine, change, or overthrow an established order. ${ }^{13}$ In literature, subversion is very often associated with parody and satire, which use traditional elements for the purpose of ridicule and harsh criticism. As the misogynist example cited above demonstrates, women have been animalized and repressed throughout history as part of a certain social agenda, which aimed to control women through controlling their bodies and sexualities ${ }^{14}$ (Pérez Gil, 1996: 106). What then, in terms of Foucault's resistance from within power, could be more subversive than using the very weapon of patriarchal oppression as an empowering strategy?

\footnotetext{
${ }^{13}$ See the study of María del Mar Pérez Gil on the feminine aesthetics of subversion in her 1996 La subversión del poder en Angela Carter.

${ }^{14}$ Many other important critics such as Gayatri Spivak discuss male anxiety about female sexuality and the political implications of the need to control women's bodies, as linked with such institutions as the nation and the family $(1981,181)$.
} 
As a literary tool, animalization could be defined as the process of characterizing a human being with more primitive, wild, instinctive, animal features, and could be said to constitute the opposite of personification. The connection between animals, nature and women on the one hand and civilization and men on the other will be explored throughout this new analysis of animalization. Of course, the distinction between nature and civilization is far from a postmodern invention, given the fact that fairy tale revisions are deeply rooted in the original folkloric oral traditions. The connection of what we consider a postmodernist strategy and its long-forgotten origins ${ }^{15}$ is explored by Jack Zipes in Fairy Tales and the Art of Subversion (1983: 43-45). Zipes briefly mentions the social and psychological implications of wild "animal nature" versus civilization and applies them to "Little Red Riding Hood." The explanation entails the awareness of the "double face" of our nature: "cultural nature" and "animal nature," both of which must be assimilated in order to reach maturity (cf. Ibid: 45). Zipes further explains:

\begin{abstract}
In facing the werewolf and temporarily abandoning herself to him, the little girl sees the animal side of herself. She crosses the border between civilization and wilderness... Her return home is a move forward as a whole person. She is a woman, self-aware, and ready to integrate herself in society with awareness. (Ibid.)
\end{abstract}

Thus, animalization can serve as a psychological tool for understanding oneself and one's identity. In her analysis of "Little Red Riding Hood" rewritings, Susan Sellers remarks on the "insistence on bestiality as a positive step" as being "a particularly prominent theme" (2001: 119-120). In fact, the literary strategy of animalization is present in many postmodern tales: "this return to the animal body free from external prescription" allows the female protagonist to relate to the male "as an equal and without fear" (Ibid. 120). ${ }^{16}$ This concept is strongly linked to the repression of female sexuality advocated by Perrault's tale which "instead of warning girls about the dangers of predators in forests... warns girls against their own natural desires, which they must tame" (Zipes 1983: 45). The need to change this oppressive vision of female

\footnotetext{
${ }^{15}$ The $17^{\text {th }}$ century French oral folk tale contains the additional elements of cannibalism, as the girl eats and drinks her grandmother, and strong sexual content of the girl burning her clothes in the fire and finding herself in bed with the wolf/werewolf, all as part of an initiation ritual.

${ }^{16}$ This opinion of bestiality viewed in a positive light is shared by Aidan Day (Sellers, 2001: 120).
} 
sexuality and the traditionally accepted social order is undertaken by Angela Carter and Carmel Bird in their revisions of the tale.

The literary strategy of animalization will be explored in three aspects, each reflecting a different subversive notion of gender representation: bestiality, instinctive sexual drive, and silence, which are fused together in the animalized images of Little Red Riding Hood. Bestiality and its inherent connection with monstrosity and the grotesque ${ }^{17}$ subverts women's traditional passivity and marginalization as inferior beings; the notion of instinctive sexual drive, obviously linked with corporeity, empowers repressed female sexuality, while silence is used as a subversive double metaphor meaning both impotence and resistance within patriarchy and its hegemonic language. It must be noted that these diverse facets of animalization have been found problematic and have seldom been analyzed together as a useful literary strategy. Thus one of the aims of this dissertation is to offer a new, critical and unifying perspective of animalization. While bestiality represents strength and domination within the social power structure, the instinctive sexual drive is connected to corporeity and sexuality. Silence does not initially seem to fit into the fierce image of instinctive bestiality, since it has always been associated with marginality (Rodríguez Salas, 2009: 92). Women, as well as animals, have historically been regarded as marginal beings connected with instinct and sensuality rather than logic, language and learning. ${ }^{18}$ Silence thus becomes a powerful metaphorical tool used to illustrate women's impotence, but also to reveal the artifice of the oppressive patriarchal ideology hidden in language.

\footnotetext{
${ }^{17}$ The creative possibilities of the female grotesque are explored in detail by Russo in her 1996 The Female Grotesque: Risk, Excess, and Modernity and by Rodríguez-Salas and Andrés-Cuevas in their 2011 study entitled The Aesthetic Construction of the Female Grotesque in Katherine Mansfield and Virginia Woolf.

${ }^{18}$ This idea of women as animalistic and therefore inferior beings has been echoed throughout the centuries by Augustine, Rousseau, Darwin, Nietzsche, Freud, Kant, Hegel, and more recently by Marks, de Courtivron, Kristeva, and Jardine (Rodríguez-Salas, 2011: 29).
} 
Let us focus on the first aspect of animalized representation: the concept of bestiality ${ }^{19}$ or monstrosity and its connection with female representation. Animals, as well as women, have frequently been conceived as "the archetypal cultural 'other'"20 (Baker, 1993: ix - x), thus it is no surprise that animal representation should have a special meaning in the symbolic construction of female identity. It has further been suggested that the "nature-culture" opposition entails assumptions about gender inequality: "in as far as humanness is equated with the shaping of culture and history, men are made to appear more human than women. Women are commonly thought of as more biological than cultural, and are taken to be closer to animals than men" (Noske qtd. in Baker, 1993: 79-80). These comparisons lead us to the obvious conclusion that in the binary oppositions nature-civilization, animal-man, woman-man, monster-human the first term is always culturally constructed as negative and somehow repressed. Baker further explains: "In the post-Cartesian west, where binary oppositions are still used at large, animals seem to figure so overwhelmingly negatively in our imaginative and our visual rhetoric. We objectify the animal and keep it at a distance" (1993: 116).

In the $20^{\text {th }}$ century fantasy regains the power to reveal the hidden and the repressed: "much of what we feel in life can easily enough be represented in realistic terms, but some of the experiences that move us most derive from more alien realms of experience, which we have represented in literature through the use of fantasy" (Hume, 1984: 43). There is a connection here with the numerous monsters found throughout fantasy literature, especially within the Victorian Gothic. ${ }^{21}$ Monsters inspire fear and at the same time fascinate, given their inherent connection with the forbidden dark desires society forces us to repress. Cohen defines

\footnotetext{
${ }^{19}$ The concept of bestiality has been analyzed as a positive and constructive force by Susan Sellers and Aidan Day.

20 The postcolonial concept of "the other" or "the subaltern" as the inferior element in binary oppositions is prevalent in Said, Bhabha, Ashcroft, and Spivak.

${ }^{21}$ There is an important connection of the Gothic with Angela Carter's tale "The Company of Wolves." Critics such as Lucie Armitt emphasize the importance of the Gothic by arguing that Carter's collection The Bloody Chamber "rather than being fairy tales which contain a few Gothic elements, are actually Gothic tales that prey upon the restrictive enclosures of fairy-story formulae" (qtd. in Benson, 1998: 52). Due to the limits of this MA thesis, the full implications of the Gothic in "The Company of Wolves" cannot be analyzed in detail.
} 
monstrosity as "a refusal of classification, a destabilisation of boundaries and normality" (1996: 7). In this way, elements of dark fantasy such as monsters, signifying chaos and the breaking of boundaries, shift from being outside forces to inhabit the human body and the mind. Some obvious literary examples include Dr.Jekyll and Mr. Hyde, The Picture of Dorian Gray, and the many half-human creatures, such as vampires and werewolves. It could easily be argued that there is a link between these male monsters and female monstrosity, which is the theme of this dissertation. After all, the animalization of Little Red Riding Hood places her on the border between animal and woman, and monster and human. In demonology the connection between women and monsters has been traced back to men's fear of women's reproductive powers and their sexual insatiability. ${ }^{22}$ Satan's army is said to have been created by the witches' endless copulation with the devils, not to mention biblical Adam's first wife Lilith, who was turned into a monster because she refused to be submissive to Adam. Apparently, the dichotomy of women as angels or demons has existed since biblical times and is inherently connected to religion and the social construct of morality.

There is also a connection between bestiality or monstrosity, and the grotesque, within the realm of dark fantasy. Hume further remarks that "the serious quest for novelty has forced writers to examine the grotesque, the acutely abnormal, and the unique" (Hume, 1984: 40). In modern tales animalization constitutes a type of grotesque, distorted intertextual version of a well-known character, which is used to criticize traditional notions of gender roles as represented in fairy tales. The Bakhtinian notion of the "carnivalesque" subverts the hegemonic vision of the world as it offers a liberating paradigm through chaos, marginality and grotesque representation. Intertextuality, or Bakhtin's chain of discourse, serves to discover the hidden meaning of the text (1982: 257-258). The original fairy tale is twisted into a focus on marginalized characters, such as the strange and wild girl from Carmel Bird's story "Cave Amantem." This distortion also serves the purpose of the means of escaping for women trapped in a patriarchal society and a road to self-discovery.

\footnotetext{
${ }^{22}$ Lecture by Professor Gregory Claeys from the University of London (Granada, April 2014).
} 
Rosi Braidotti's theories connect women to monsters in order to dismantle patriarchy's strategy of presenting the female as the marginal other through a cultural process of subordination (1994: 64). Braidotti further explores the ambivalence which surrounds the "monsterisation of women" through the etymological origins of the Greek word "monster", meaning horrible and wonderful at the same time (Ibid. 62). Both women and monsters fascinate and inspire fear; their construction as an abnormality leads to the need for their repression within the hegemonic system. Braidotti thus defines the monstrous body:

\begin{abstract}
The monstrous body, more than an object, is a shifter, a vehicle that constructs a web of interconnected and yet potentially contradictory discourses about his or her embodied self. Gender and race are primary operators in this process. As a way of concluding, I would like to propose a redefinition: the monster is a process without a stable object. It makes knowledge happen by circulating, sometimes as the most irrational non-object. It is slippery enough to make the Encyclopaedists nervous; yet, in a perfectly nomadic cycle of repetitions, the monstrous other keeps emerging on the discursive scene. As such, it persists in haunting not only our imagination but also our scientific knowledge-claims. Difference will just not go away. And because this embodiment of difference moves, flows, changes; because it propels discourses without ever settling into them; because it evades us in the very process of puzzling us, it will never be known what the next monster is going to look like; nor will it be possible to guess where it will come from. And because we cannot know, the monster is always going to get us. (Braidotti, 300)
\end{abstract}

This explanation links the animalized, monstrous body with numerous discourses on domination and submission, as well as with the shifting, unstable, nomadic identity. Female identity has often been interpreted as a "becoming process" ${ }^{23}$, thus connecting with Braidotti's view of the monster as "process." According to this feminist critic, nomadic subjects express "the desire for an identity made of transitions, successive shifts, and coordinated changes, without and against an essential unity" (1994: 22). In other words, the notions of monstrosity and animalization are linked to the female identity and the female body in that they destabilize the accepted order and harmony, given their chaotic and volatile nature. In the following chapters we will see how Carter and Bird make use of these shifting identities and the irrational circular discourse on monstrosity to create new paradigms.

\footnotetext{
${ }^{23}$ This view is shared by many feminist critics: Simone de Beauvoir, Judith Butler, Rosi Braidotti, Margaret Atwood, among others.
} 
Related to the concept of monstrosity, Kristeva's notion of the "abject" or the "uncanny" is explained as "what disturbs identity, system, order. What does not respect borders, positions, rules" (Kristeva, 1982: 4). Within the "abject" then, some repressed notions of social taboos seem to be hidden. It is in this liminal space ${ }^{24}$ away from binary oppositions, somewhere between the subject and the object, in the "abject" that women can construct their identities. This concept of the "abject", as applied to the strategy of animalization, helps rewrite it as a (de)constructive tool for discovering Braidotti's "nomadic" female identity. This is partly why, far from being a grotesque feminist cliché, animalization is employed in order to shock and surprise. While exploring new possibilities, it reveals the strength and rage of women as wild and free beings, rebelling to escape a repressive social structure. This way, the traditionally oppressive strategy of animalization can be rewritten as a creative paradigm, in which women are metaphorically or literally linked with the beast ${ }^{25}$ through strength, monstrosity, the grotesque, the abject and fantasy, elements which subvert women's marginal position throughout history.

The second aspect of animalization is instinctive sexual drive, as linked with corporeity and female sexuality. In her essay "About Chinese Women" Kristeva remarks: "God generally speaks only to men [...]. Woman's knowledge is corporal, aspiring to pleasure rather than tribal unity (the forbidden fruit seduces Eve's senses of sight and taste)" (1986: 140). While taking into account all the theoretical animal-female links discussed previously, we need to focus on the subject of the female body and sexuality in detail.

The male appropriation and objectification of the female body has also been seen as the repression of female intelligence and creativity. Important critics such as Gayatri Spivak discuss

\footnotetext{
${ }^{24}$ The notion of a liminal space or Bhabha's theory of "third space" as a way to subvert binary oppositions is also key in Post-colonial theory.

25 There is an intriguing double meaning here: firstly, animalization can be classified as more literal or metaphorical, and secondly, in the specific context of postmodern fairy-tale rewritings there is a metaphorical or literal relationship between the girl and the wolf.
} 
male anxiety about female sexuality and the political implications of the need to control women's bodies, as linked with such institutions as the nation and the family (1981: 181). In order to achieve true freedom, a positive re-appropriation of the female body is necessary. In "The Laugh of the Medusa" Cixous explores the transgressive power of the "wild female self" and writes that women must celebrate their own bodies in literature and reclaim their language, history and their lives (1990: 1232). According to Luce Irigaray, "femininity is a role, an image and a value imposed on women by masculine systems of representation. In this masquerade of femininity, the woman loses herself, and loses herself by playing on her femininity" (1996: 84). In order to deconstruct the artificiality of gender representations Irigaray develops the concept of "mimicry" modeled on the earlier notion of "masquerade." Both concepts prove to be resistance strategies inherently linked to parody and exaggerated imitation (qtd. in Rodríguez-Salas, 2011: 11). Instead of offering arguments through logic, women rebel by a subversive exaggerated imitation of gender roles, through which they reveal artificial notions of representation and criticize their exploitation within the existing patriarchal social order (Irigaray, 1991: 78). This distancing from the artificial construct of gender representation is likewise evident in the concept of "performativity", which is developed in reference to the subversion of female identity in Butler's 1990 Gender Trouble. Butler understands gender as "an ongoing discursive practice... open to intervention and resignification" $(1990,33)$. She further claims that "there is no gender identity behind the expressions of gender" because "identity is performatively constituted by the very 'expressions' that are said to be its results" (Ibid.). These hybrid and (de)constructive visions of gender identity correspond with the liminal and heterogeneous representations of the monstrous body. If identity can be constructed through actions, then women writers should partake in its creation through cultural representations.

Given that animalization distorts, but at the same time reclaims female sexuality, it should be seen as part of the revolutionary effort to undermine patriarchal paradigms. This subversive strategy seems to be a reply to centuries of over-victimizing women and envisioning them as passive objects. Through an abject representation of the sexual drive, this strategy helps 
construct a subversive vision of female sexuality freed from oppression. This aspect of animalization could be described as sensual, erotic and even pornographic (Bacchilega, 1998: 38). The reference to animalistic sensuality as pornography has sparked massive debate, as some critics question the constructive possibilities of "pornography" (Ibid. 37) and the use of patriarchal "weapons" as subversive strategies. Angela Carter for one does believe in this subversive possibility and has referred to the notion of "moral pornographer" (Ibid. 38). These criticisms could in part be contested by Foucault's concepts of resistance from within power and Kristeva's influential revolt from within the hegemonic order of the social-symbolic (qtd. in Sellers, 2001: 30). The previously discussed notions of the female grotesque and the abject are vital for this second aspect of animalization: it allows "the abject woman to unchain herself from her oppressive confinement to the category of the beautiful and to retrieve a self of her own" (Rodríguez-Salas, 2011: 29-30). Thus, animalization, far from a mere pornographic representation of gender roles, subverts traditional concepts of femininity and offers a new model of female liberation. Through the appropriation of her own instinctive sexuality, the new Little Red Riding Hood defies oppression in the realm of male-female hierarchical sexual relations and at the level of social intercourse at large.

The analogy between the cultural construction of animals and women as inferior, instinctive, and marginal beings, which have been dominated, has already been discussed at large. In the strategy of animalization, the third inherent connection between animals and women is constituted by their mutual silence within the hegemonic order of patriarchal language. The powers of language to construct and control our reality are discussed by Louis Althusser in his 1969 article "Ideology and the State." Pam Morris explains that:

[Language] continually "reproduces" reality as a hierarchy of values which sustains the interests of dominant power. Language is the means by which these hierarchical values seem to us natural and true. It is in the interest of power to impose this ideological perception of reality as the only possible one, the unitary "Truth." (1996: 137) 
History, postcolonial discourse, and Feminism abound in examples of marginal beings "silenced" by the colonizer or the oppressive system. Postmodern literature also tends to focus on absences and silences, all connected to Foucault's concepts of Counter-Memory and Counter-History in order to retrieve the elements eliminated by the dominant ideology. Bakhtin's carnival, through its momentary subversion of the world order, parody and the grotesque brings the silences and marginalities into focus. Silence also evokes a connection to Kristeva's notion of the semiotic, which is associated with women and the pre-linguistic phase, as opposed to the male linguistic phase of the symbolic, as well as her strategies for dissident writing. Language dominated by men has always been a feminist concern, in which silence, from being perceived as passive submission, has become one of the weapons of rebellion. Manuela Palacios González further explains this strategic use of silence:

[S]ilence as a strategy for resistance can only be envisaged as a first stage in the production of alternative ideologies. It is difficult to imagine how it can win other individuals and increase its power if it is not in circulation. In spite of its limitations and of our awareness that silence is the effect of power, it may be considered as a potential temporary strategy for the destabilization of hegemonic interests. (2001: 203)

In Post-colonial texts, silence has also been interpreted as a liberating strategy, given that it "indicates a potential and shifting horizon of possible meanings" which "cannot be overwhelmed by any interpretation" (Ashcroft, 1989: 184). Silence is thus used as a subversive strategy, first to destabilize the hegemonic order, and later to reveal oppressive ideologies and offer strategies of resistance. $^{26}$

Thus the subversive strategy of animalization includes three major aspects: bestiality, instinctive sexual drive, and silence, all linked through intertextuality, which allows the reader to discover new meanings in well-known fairy-tale characters such as the Little Red Riding Hood. Throughout the analysis of Angela Carter's and Carmel Bird's stories we will focus on the

\footnotetext{
${ }^{26}$ Gerardo Rodríguez-Salas analyzes the strategic use of silence in "The Boundless Ocean of Silence: An Alternative to Language in Katherine Mansfield's “Doll's House"” (2007).
} 
different types of animalization, ranging from "symbolic animalization" to "literal animalization." "The Company of Wolves" and "Cave Amantem" will be analyzed taking into account the type of animalization, which in turn contributes to the portrayal of each character's literal or metaphorical freedom from the oppressions of patriarchal society and the psychological development of their identity. There exist no serious studies that fully explore the subject of animalization in relation to "Little Red Riding Hood" revisions, a long-underestimated connection. Therefore it is the goal of this work, through systematic and comparative analysis of this subversive strategy and its evolutionary exploration of "the beast within," to give an insight into female self-discovery and alternative conceptions of freedom. 


\section{Chapter 2}

\section{The “infernal” desires of Angela Carter: “The Company of Wolves" (1979)}

\subsection{Angela Carter's gothic forest}

Angela Carter is perhaps the first name which comes to mind when we think of modern revisions of fairy tales. ${ }^{27}$ Her contribution to the retelling of the fairy tale has become an inherent part of her, so much so that she is remembered as a "benevolent witch-queen" and the "Faerie Queene" (cf. Benson, 1998: 31). The story to be analyzed is found in her collection of tales The Bloody Chamber published in 1979. This collection, according to Salman Rushdie, is Carter's most memorable accomplishment, a "masterpiece... the most likely of her works to endure" (Ibid.). This collection is indeed a literary milestone as it has been said to have "turned the key" opening the door to a "hidden room" of women's sexuality and desire (cf. Bacchilega, 1998: 22). Her stories have additionally been analyzed as "Gothic tales" (Armitt, Wisker), thus emphasizing the importance of horror in Carter's layered genre intertextuality. ${ }^{28}$ Lucie Armitt, for instance, focuses on the "spaces and frames of the Gothic" within The Bloody Chamber (Benson, 1998: 34). The Bloody Chamber has also been called "a gleeful, subversive commentary on her earlier work" (cf. Benson, 1998: 61). This remark can easily be applied, among others, to Carter's earlier translations of Charles Perrault's fairy tales (Bacchilega, 1998: 9). These translations submerged Angela Carter in the world of the fairy tale and have inevitably influenced her creative literary universe.

"The Company of Wolves" is the most famous of the three tales known as Carter's Little Red Riding Hood trilogy. Although all three focus on retelling the ancient folk tale of the innocent girl and the wolf from different perspectives, the chosen short story is the one which best

\footnotetext{
${ }^{27}$ Rodríguez Salas (2010) problematizes Carter's female empowerment in the context of the fairy tale.

${ }^{28}$ Some aspects of fantasy, horror, and the Gothic have been incorporated into the analysis of monstrosity. A more specific focus on horror and the Gothic is among future goals for a PhD thesis.
} 
exemplifies subversive animalization. ${ }^{29}$ Before starting the analysis it is important to keep in mind that in Postmodern literature all final truths and straightforward conclusions disappear; rather different levels of meaning emerge as "presence is replaced by... volatile and unstable identity - beast or beauty, tiger or bride, wolf or girl" (Ibid. 18). "The Company of Wolves" reveals controversial issues hidden under the surface of the original "Little Red Riding Hood."

This story is Carter's most well-known retelling of the Little Red Riding Hood, particularly due to its 1984 film adaptation by Neil Jordan. However, it must be admitted, there is little consensus when it comes to explaining the meaning of Carter's tale, possibly because the intention to "lay a grid across her work and read off meanings from it" (cf. Benson, 1998: 45) has always failed utterly. This literary discussion has generated numerous opinions on the subject. While it is virtually impossible to explain it all, even a fraction of the tale is worth it, always keeping in mind two things: the "space for the reader's activity", this individual interpretation to which Carter kept her tales open, along with "her constructive avoidance of closure," which could be "recognized as her adoption of the model of folkloric narration as an ongoing process" (Ibid. 46). While Carter "questions and provokes her fairy-tale sources" (Ibid. 46), she also participates in that tradition by retelling the stories.

In this particular instance, we find an introduction to the superstitious cold world of the upland woodsmen of the northern country. According to the fairy tale tradition of the timeless present, no specific details are mentioned, except that it is winter. Curiously, the narrative presents itself, in an echo of Perrault's version, as a cautionary tale, warning all "unwary travellers" of the dangers of the wolves: "Fear and flee the wolf; for, worst of all, the wolf may be more than he seems" (Carter, 1979: 138). ${ }^{30}$ Yet this warning is not completely one-sided: on the one hand there are horrific references to wolves as "shadows... wraiths, grey members of a congregation

\footnotetext{
${ }^{29}$ Due to space limitations only one of Carter's stories could be used in this dissertation. A more in-depth analysis of Carter's Little Red Riding Hood trilogy is among future goals for a PhD thesis.

${ }^{30}$ From now on, references to Carter's tales will appear parenthetically only with an indication of the page number.
} 
of nightmare" (137), ${ }^{31}$ and on the other there is an attempt at providing an explanation for their actions and even a tinge of sympathy for them: "wolves grow lean and famished" (137), "that long-drawn, wavering howl has... some inherent sadness in it, as if the beasts would love to be less beastly if only they knew how and never cease to mourn their own condition" (139). Right at the opening of the narrative Carter proves that a single truth is impossible. Thus the oral storyteller makes an effort to reveal different aspects of the tale, which we then piece together as we may. The ability to decode as an active reader allows us to follow the main narrative along with the numerous oral folk tales. It would be impossible to analyze all the stories found in "The Company of Wolves" in depth, so after a brief reference to these folk tales, we will focus entirely on the main narrative about the wolf who was more than he seemed.

The stories embedded in the narrative tell of werewolves, witches, all types of transformations; while retrieving the oral tradition, these tales include some critical social and religious references, and clearly reveal Carter's gothic streak. The many superstitions and common beliefs of the region include the existence of werewolves, the story about a witch who turned a wedding party into wolves, an ointment from the Devil, and the belief that "if you burn his [a werewolf's] human clothing you condemn him to wolfishness for the rest of his life" (140). There are also some comments which seem to be critical reflections on humanity and society. The most mysterious of these is the following sentence: "We keep the wolves out by living well" (143). This statement offers various possible interpretations. The one that seems to fit best is related to the concept of evolutionary psychology. Basically, because we "live well," and all of our primary needs are fulfilled, we have lost the need to resort to our instinctive wild side. Even nowadays we would prefer to forget the existence of this instinctive part of us because it scares us. So we live in our world of culture, religion and morality and condemn any sign of animalistic instinct. This would explain why the notion of animalization brings "distaste" to many, as it subverts our socially-learned values and shows us something disturbing. Angela Carter herself

\footnotetext{
${ }^{31}$ Let the clearly religious reference not be lost, along with many others which seem to criticize religion: "The wolfsong is the sound of the rendering you will suffer, in itself a murdering" (137).
} 
seems to confirm this explanation with the following statement: "I do think that the body comes first, not consciousness... I often shatter pure and evocative imagery with the crude. But remember there's a materiality to symbols and a materiality to imaginative life which should be taken quite seriously" (cf. Bacchilega, 1998: 7).

Now let us focus entirely on the main narrative: the tale about the girl and the wolf, which is subversive in both characters and plot. Right from the beginning, the girl is described as pure and innocent, yet also a "strong-minded" child who "insists she will go off through the wood" (141). On her way she encounters a young and handsome man, with whom she wages a bet about who will arrive at her grandmother's house first. Just like in the traditional versions, the grandmother is eaten, and the werewolf waits for the girl. What happens from the time the Little Red Riding Hood enters the house has many possible interpretations. In short, it could be defined as much as a personal struggle for her own safety as a successful seduction. Who seduces who and why is less clear and will be discussed in detail in the last section of this chapter. One could wonder whether the girl retains her human shape or becomes a werewolf, as is suggested by the film adaptation of the tale. In the story it is not made clear, yet no references to her transformation are present. What is clear is that the ending is subversive and cryptic: "See! Sweet and sound she sleeps in granny's bed, between the paws of the tender wolf" (147).

\subsection{The seduction of the wolf}

In "The Company of Wolves" we find that the strategic use of animalization involves references to all of its three components: bestiality, instinctive sexual drive, and silence. The oral narrative technique of this cautionary tale warns us above all about a wolf who "may be more than he seems" (138). The caution does retain an echo of Perrault, yet it is much more ambiguous, as it could be interpreted in either a positive or negative way. A wolf may be "more than he seems" in that we have somehow misjudged him by perceiving him as purely evil, or in Perrault's sense 
the quote might refer to a wolf hiding under a cunning disguise. In this tale both possibilities are implied as the werewolf of the story is certainly more than he seems. The narrator warns us about the wolves, but also tries to convey "their side of the story." This ambiguous notion adjusts perfectly to Cohen's definition of monstrosity as "a refusal of classification, a destabilisation of boundaries and normality" (1996: 7). In this tale, both the wolf and Little Red Riding Hood are also more than they seem according to Braidotti's monster theories of disrupting the accepted system and breaking existing limits.

When the main narrative begins, we immediately perceive a difference between this new Red Riding Hood and the original little girl. Carter's character is described from the very beginning as a "strong-minded child" who "insists she will go off through the wood" (141). Unlike the traditional character, this postmodernist one does not go on an errand for her mother; she makes her own decision to go, even though she defies her father, who would not have let her go had he been home. The lack of a patriarchal figure gives the girl a possibility of freedom and maturity. The story begins with a personification and animalization of the forest: "The forest closed upon her like a pair of jaws" (141). This ominous image foreshadows the dangers she will encounter. Let us examine the subversive animalization of Red Riding Hood in detail.

Whereas, in the $19^{\text {th }}$ century version, the Brothers Grimm remove all sexual references from the tale, in Carter's "The Company of Wolves" the descriptions of the girl are full of sensual details which foreshadow the sexual encounter in the last scene. The following quotes paint an erotic image of instinctive sensuality and hint at some animalistic traits of Red Riding Hood:

\footnotetext{
Children do not stay young for long in this savage country. There are no toys for them to play with so they work hard and grow wise but this one, so pretty and the youngest of her family, a little late-comer, had been indulged by her mother and the grandmother who'd knitted her the red shawl that, today, has the ominous if brilliant look of blood on snow. Her breasts have just begun to swell... her cheeks are emblematic scarlet and white and she has just started her woman's bleeding. (141)

She stands and moves within the invisible pentacle of her own virginity. She is an unbroken egg; she is a sealed vessel; she has inside her a magic space the entrance to which is shut tight with a plug of membrane; she is a closed system; she does not know how to shiver. She has her knife and is afraid of nothing. (141)
} 
The girl with the red shawl is presented as pure and innocent, and as a "strong-minded child" who is fearless because she has yet to experience the world. She is just becoming a woman and does not yet know what that entails. She is an "unbroken egg" a "sealed vessel," a "closed system," untouched by any man or by the cruel reality of the world. The circular metaphors in this section could be interpreted as Kristeva's notion of the Semiotic and the eternal feminine linked with the cycles of nature, and thus inherently with sexual reproduction. The girl has enjoyed safety and love in the safe bubble of her familiar world. Fear is generated by terrible experiences, and she has none. She "has her knife" and is prepared to venture into the forest of life. These traits create an image of instinctive strength, animalistic fearlessness and determination, which shift the girl's identity towards a web of contradictory discourses as theorized by Braidotti in her theory of nomadic subjects. There is another interesting chain of metaphors connected to her red shawl, as seen on her white skin, which once again reflects Kristeva's notions of the eternal feminine and the order of the Semiotic. In this first description we are given the first piece of the puzzle; her shawl has the "ominous look of blood on snow." This could be interpreted as her introduction into what life is. Blood symbolizes pain and death, but it also hints at sexual initiation and life. The snow, apart from implying her purity, could also reflect on life, which is not untouched purity and goodness; it involves pain, sacrifice, and suffering, as she is about to learn. The colors of her cheeks, "emblematic scarlet and white," confirm the previous metaphor of life burning in her. Through this instinctive representation, the girl is further linked with Kristeva's pre-linguistic Semiotic, and distanced from the dominant language and logic of the Symbolic order. The whole description is considered subversive animalization because it connects the girl, almost a woman, with her body, by what Cixous referred to as a transgressive celebration of the female body and one's own instinctive sensuality, in order to reclaim women's language, history and their lives (1990: 1232). This part of female identity has always been associated with the pleasure of men. In this case, Carter combines the strategic use of silence with a transgressive vision of female sexuality in a web of contradictory paradigms. It is this instinctive sensuality which opens up the way for the new Red Riding Hood's sexuality to emerge. This description is a way of rediscovering that which has been traditionally been twisted into immorality, shame and sin. 
As the girl in red walks through the forest, she encounters a handsome hunter. In contrast to her animalization, the hunter, who is in fact a werewolf, is personified. She realizes that she has "never seen such a fine fellow before... so they went together, through the thickening light of the afternoon" (142). The young man is a gentleman: he offers to carry her basket and "she gave it to him although her knife was in it because he told her his rifle would protect them" (142). In her infinite trust of the world, she places her life in the hands of this young "dashing huntsman." Of course she is naïve, but then again who is not when giving into the desires of the heart? The personification of the wolf becomes more evident, as he is not only associated with a young handsome huntsman, but also with a worldly and learned man. In this tale the monstrosity of the wolf, as theorized by Braidotti, clearly disrupts the existing boundaries and binary oppositions. The werewolf in Carter's story escapes classifications, as he is both beast and man, instinctive animal and learned gentleman. Carter's innovative symbol is the compass, which works as a clear opposition to the path; hence the order of the symbolic, knowledge and logic is linked with the werewolf, while the girl's impotence is revealed by her association with the pre-linguistic silence of the Semiotic order. The fact that this object is associated with the wild werewolf makes us question his condemnation. He laughs when she tells him that "she should never leave the path... or she would be lost instantly" (142). The werewolf huntsman challenges the established social norms, while his compass seems to be a metaphor of free thought, science and experiment, in clear opposition to the superstitious-ridden, socially and religiously oppressed world. The young man proposes a bet because she does not believe he can get to her grandmother's house faster stepping off the path and using his compass; if he wins he gets a kiss. Hence the beginning of what is termed "a rustic seduction." All throughout the tale this personification of the wolf is linked to an intent of somehow justifying his actions: "that long-drawn, wavering howl has... some inherent sadness in it, as if the beasts would love to be less beastly if only they knew how and never cease to mourn their own condition" (139). In the very last line of the tale the wolf is also described as "tender," (147) thus clearly questioning the traditional image of the "big bad wolf." 
Yet the werewolf is still true to his animal nature, he is "carnivore incarnate" (144). The pious grandmother tries to throw her bible and then clothes at him to protect herself against "these infernal vermin" (144). But nothing seems to work: "now call on Christ and his mother and all the angels in heaven to protect you but it won't do you any good" (144). Carter's repeated criticism of religion as useless protection against the world's evils is evident. There are two magnificent images of the wolf as night and nature: "The sticks in the hearth shift and hiss; night and the forest has come into the kitchen with darkness tangled in its hair" (144), "his nipples are ripe and dark as poison fruit" (144). This erotic description brings to mind the biblical forbidden fruit. Carter might be hinting at sexuality being the forbidden fruit for which Red Riding Hood will reach. The young man takes off his clothes, transforms into a wolf and eats the grandmother. Now it is time to wait for Little Red Riding Hood. The scene which unfolds as she walks in and realizes he has killed her grandmother has many possible interpretations.

The girl comes in "bringing with her a flurry of snow that melted in tears on the tiles" (145), another example of foreshadowing of both innocence and sorrow. Her first reaction upon realizing what has happened is the animal instinct to defend herself: "She knew she was in danger of death," "she wanted her knife from her basket but she did not dare reach for it because his eyes were fixed upon her..." (145). She asks about where her grandmother is, to which he replies "There's nobody here but we two, darling" (145). His eyes shine with a "diabolic phosphorescence" (145), his first instinct being to devour her. She realizes that they are surrounded by wolves and her chances of surviving are rather slim, yet she also feels sympathy for them: "It is very cold, poor things... no wonder they howl so" (146). The red of her shawl is once again compared to the "blood she must spill" (145) and further on to "the colour of poppies, the colour of sacrifices, the colour of her menses" (146). These cyclical metaphors are relevant in terms of Kristeva's notion of the pre-linguistic Semiotic and the eternal feminine. All of these references make for a possible argument of her virgin sacrifice to the wolf. It seems that she consciously makes this decision and she no longer shivers: "since her fear did her no good, she ceased to be afraid" (146). Interestingly enough, now her actions seem very 
calculated and logical. We could interpret this as her taking on a different approach to save her life. At the beginning of the tale we are told that "the wolf is the worst for he cannot listen to reason" (138), yet it is not reason that she resorts to, but her animal sexual instinct. Thus, she offers herself as a sacrifice to the wolf; she has learned how the world works: "the wise child never flinched" (146). The echoes of the original tale resound in "What big arms you have. All the better to hug you with" (146) as the not so Little Red Riding Hood seduces the wolf:

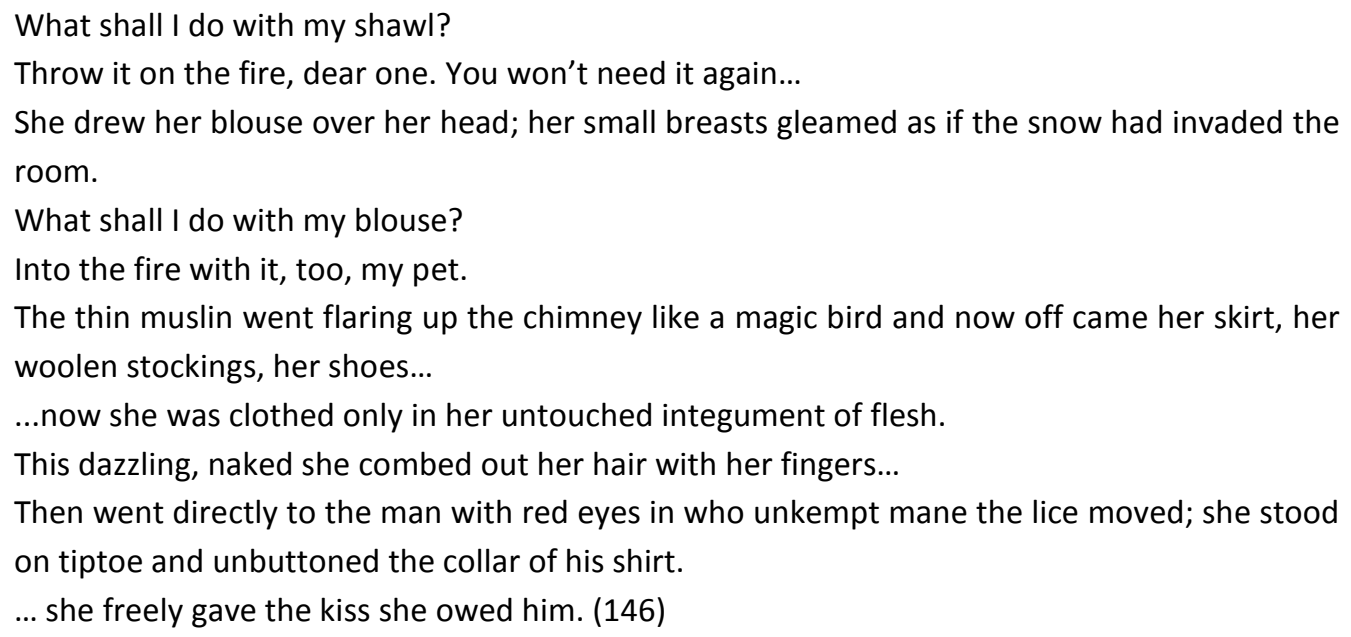

This scene has been interpreted according to the concepts of masquerade, Irigaray's notion of mimicry, and Butler's theory of performativity by critics such as Catherine Lappas (Benson, 1998: 42). Red Riding Hood's animal instinct shines through as she sensually changes the fire in the werewolf's eyes from hatred to desire. There is parody or mimicry of traditionally accepted gender representations in order to dismantle their artifice. Another critic similarly suggests that this "self-conscious enactment of femininity" is "a means of deconstructing its traditional status as self-evident image" through a process of denaturalization (Doane qtd. in Benson, 1998: 42). It is important to note that the girl is not submissive; she is sure of herself: she "knew she was nobody's meat" (147). Butler's notion of performativity is likewise made evident in the theatrical actions of the heroine: "She laughed at him full in the face, she ripped off his shirt for him and flung it into the fire" (147). Not only is she erotic, but she could also be said to embrace her wild instinctive side as she takes the initiative in the sexual encounter. It is made clear that "she freely gave the kiss she owed him," thus giving her control and freedom over her 
body, something which according to Spivak has been denied to women due to social, political and religious agendas. The notions of Cixous are clearly reflected in Red Riding Hood's transgressive appropriation of her own body and sexuality, while her instinctive actions of ripping off his shirt once more emphasize her silent strategy of resistance. Perhaps through burning his clothes, she condemns him to a lifetime of wolfishness, if we believe the superstition, yet she does the same with her clothes. The animalization of Red Riding Hood is subversive, in that it creates new liberating paradigms; to quote Sellers, "this return to the animal body free from external prescription" allows the female protagonist to relate to the male "as an equal and without fear" (2001: 120). In terms of Braidotti's monster theories, this erotic bestiality, which leads to the girl's possible transformation into a werewolf, constitutes a rejection of categories and hierarchical models, but also a way to embrace animalistic silence as criticism of the dominant system. The constructive possibilities of Kristeva's theories are evident further on:

She will lay his fearful head on her lap and she will pick out the lice from his pelt and perhaps she will put the lice into her mouth and eat them, as he will bid her, as she would do in a savage marriage ceremony. (147)

Kristeva's notion of the "uncanny", as illustrated by the savage rites of the marriage ceremony, disrupts the rules of the system. It is in this liminal space, theorized by Bhabha as "third space," away from binary oppositions, somewhere between the subject and the object, in the "abject" that the new Red Riding Hood constructs her identity. Perhaps she herself will become a wolf, something that is implied by the film adaptation of the story, thus breaking all categories. This way, the strategy of animalization is redefined as a (de)constructive tool for discovering Braidotti's "nomadic" female identity. Irigaray's mimicry is also evident in this section, as the parody and masquerade of the artificial system of male control is reflected in the command "as he will bid her." At the end of the story it is "all silent, all still," "The blizzard died down," "See! sweet and sound she sleeps in granny's bed, between the paws of the tender wolf" (147). The ending is mysterious, but we can guess that the two are lovers and the fierce wolf is now described as tender; somehow through her monstrosity she has pacified the beast by transforming his violent instincts into passionate sexual desire. The silence at the end of the 
tale might be interpreted as the marginal point of view on the story, as well as a new model of resistance to traditional gender relations, especially in terms of sexual encounters.

There has been a lot of criticism concerning this last scene. In the 1970's and 1980's there was a controversial debate involving the concept of pornography. In relation to this particular scene some critics argue that it is just a recreation of a typical sexual encounter, "the distilled essence of the entrenched binaries of patriarchal gender relations," with the dominant male and a pornographic "display of affection' strictly for his pleasure" (Benson, 1998: 37). The real controversy lies in the extent to which pornography can be read as a critique and is capable of offering some alternatives, and this is clearly a complex issue related to the definition of pornography. Carter would probably refer to this tale as partly pornographic, yet she also defended the subversive power of pornography through her notion of the "moral pornographer" (Ibid. 38). Although this notion has been fiercely criticized, I would still argue that the animalized image of the girl in Carter's story is strongly empowering and constitutes a subversive reply to a world dominated by male sexuality and desire. Yes, the girl finds herself in an oppressive situation, yet her response is the subjugation of male dominance with "that instinctive patriarchal weapon" finally detached from masculinist control. The notion of the fallen woman is also subverted. She becomes the one who initiates a given path, alas irony, which had always been deemed improper and sinful. All these delicate intricacies of women's sexuality have long been repressed. Angela Carter chooses to venture into that mysterious labyrinth of female desire and lose herself among the actions of a sensuous Eve, who somehow redeems the fallen Adam. The postmodernist notion of a "volatile and unstable identity - beast or beauty, tiger or bride, wolf or girl" is ever present in this tale (cf. Bacchilega, 1998: 18). The strategy of animalization, with its key components of bestiality, instinctive sexual drive and silence, helps to (de)construct the notions of marginality, the "Other" and that "volatile and unstable identity" theorized by Braidotti, Irigaray and Butler (Bacchilega, 1998: 18). 


\section{Chapter 3}

\section{Fingernails like claws: Carmel Bird’s “Cave Amantem” (1985)}

\subsection{The Cave of Lovers}

The second tale to be analyzed is Carmel Bird's short story "Cave Amantem," published in 1985. The title proves vitally important, as "Cave Amantem," which Bird took from Mérimée's story "La Vénus d'île," refers to the inscription in the evil bronze statue: "Beware of whomever loves you, beware of lovers." Therefore, the title strongly suggests a "love affair" right from the very beginning, and probably the evil side of the female protagonist, Isabella (or the new Riding Hood) by her connection with the bronze statue in Mérimée's story. The noun "cave" also suggests a reference to the wilderness of a past uncivilized world. This story is a prototypical postmodernist creation in the sense that it sheds light on the marginal character of Isabella. In opposition to the nameless "Little Red Riding Hood," which is meant to be a general representation of young people prone to temptation, Isabella is a strange girl with a bad reputation whose love affair with the wolf is suggested throughout the story. As the following analysis will show, this love affair can be understood in two very different ways: as a literal union with a fierce beast, or as a metaphor for a girl who "falls in love" with her wild side, which is repressed by society.

Another important aspect of the story is the postmodernist narration and the role of the active reader in the construction of the plot. Isabella's cryptic tale is revealed piece by piece by two very different narrators: a seemingly objective observer who, through very sensual poetic prose, describes her actions of burying the body of the wolf as an almost sacred heathen ritual, and a first person narrator who is one of the characters of the story, who condemns Isabella almost from her birth and who turns out to be highly unreliable due to a secret she seems to be hiding and a clearly insincere remorse for pushing Isabella onto the path leading to her supposed doom: "My son was half in love with her - half the time. He knew it was madness... 
He is very pleased now, naturally, that I stepped in" (Bird, 1985: 26). ${ }^{32}$ The two different narrators clearly mirror Kristeva's concepts of the Semiotic and the Symbolic. The Symbolic narrator of the story is logical and linear, in addition to being highly unreliable and full of prejudice. The other narrator, who tells the story in the timeless present of the eternal feminine, echoes Kristeva's notion of the cyclical and silent nature of the Semantic order. The story is not so much told as it is inferred, according to the postmodernist technique of the active involvement of the reader. Barthes explains that "the birth of the reader must be at the cost of the death of the Author" (1968: 228-32). This way, every person reading the text can use the clues given and the secrets unrevealed, to create a possible version of the story.

The short tale clearly shows Isabella's entrapment in social conventions, which she escapes through embracing her wild side and running away with the wolf. The first scene set by the Semantic poetic narrator makes the death of the wolf a fact from the beginning. Yet we are never told explicitly how he died. Isabella's killing him and then ceremoniously burying his body while tears roll down her cheeks hardly makes any sense. Another possibility is suggested later on in the story by the narration of Luis's mother; namely, there is mention of men finally hunting down and killing the leader of the pack of wolves. All this happens two years after Isabella's mysterious disappearance, while she is on an errand for Luis's mother: "Yes, I admitted it was my basket... My errand sent her to her doom in the forest. How can I forgive myself?" (27). This leaves two years of story time unaccounted for by fact. It is all our intuition. The most plausible version seems to be that Isabella used the narrator's errand as an excuse to run off with the wolf and be thought dead by the people of the village, thus escaping oppressive society. The subversive strategy of animalization is present throughout the text and is inevitably suggested by the love affair with the wolf and the other aspects of the characterization of Isabella. The elements of bestiality, instinctive sexual drive, and silence are used to subvert the existing oppressive system and to find possibilities of escape.

\footnotetext{
${ }^{32}$ From now on, references to Bird's short story will appear parenthetically only with an indication of the page number.
} 


\subsection{The monster in the heart of silence}

"Little Red Riding Hood" seeps in through "Cave Amantem" as the intertextual references or Bakhtin's notions of plurality of voices or polyphony (1982: 257-258) make us aware that it is the story of Little Red Riding Hood and the wolf. The first mention of a familiar element occurs right at the beginning of the text, when the poetic prose narrator/observer introduces the scene: "The girl is burying the body in the hollow. She has wrapped it in a scarlet cloak" (25). ${ }^{33}$ These first lines of the story are but the beginning of a familiar fairy tale, which we start to perceive more and more as the story goes on. While Bird's character is named Isabella the Little Red Riding Hood's name in the original tale derives precisely from the essential symbol of the red cloak. The color red, whose sexual association is present even in Perrault's original tale, acquires more complex meanings of corporeity, instinctive sexuality, animal bestiality and freedom, and death. Let us examine more references to the girl's cloak found in different sections of the first part of the story:

She scatters sweet herbs across the dead one who is folded and parcelled in scarlet. (25)

They [the tears] make no stain on the scarlet cloth, for the cloth is grimy, tattered at the edges, toggled with mud. It shows through the leaves and flowers, now dull red, now brown and, sometimes, on the edge of a wrinkle, vivid blood. (25)

In the castle, whole save for the roof, she wrapped the body in her cloak and carried it and dragged it to the hollow. (26)

And that red cloak - she always wore that cloak. You could see her coming for miles. Of course, her grandmother made is for her. It would have been fine for a princess on a white horse. But there it was on Isabella as she ran from one end of the village to the other, often barefoot, meeting soldiers and travelling musicians and so on in the forest. (27)

From the given examples it is evident that the symbol gains in meanings in this gendered revision of the tale. The original meaning of the red cloak as temptation, loss of innocence and maturity no longer suffices to explain this symbol in Bird. The cloak becomes a burial shroud,

${ }^{33}$ The italics in the quotations of all the texts are mine. They are meant to highlight the key aspects of animalization. 
hence adhering a relation to death, which in the feminist perception could be connected to an escape from the patriarchal system and, therefore, freedom from oppression. The scarlet cloak seems to tell a story of its own, giving us important clues as to what actually happened in the text. We know that the girl wrapped the dead body of the wolf in the cloak and dragged it in order to bury him in the hollow. In the "vivid blood" red one can easily discern a symbol of violence, death, and oppression that a marginal figure of "the other" might experience in society. In the last quote the cloak becomes once again a clear symbol of Isabella as a marginal figure. The cloak was extraordinary and fit for a princess, yet she wore it proudly as she ran barefoot to the forest defying all accepted social conventions. These references to her deviant sexuality are just the beginning of Isabella's portrayal as "the other," according to the postcolonial notion theorized by Bhabha, Said, and Spivak.

In the burial scene Isabella is described as a sensual being who sprinkles flowers on the "dead one" and whose cheeks are wet with tears. Thus shown to embrace her sensual nature, Isabella is also characterized as strong and determined:

\footnotetext{
Tears. There are tears in her eyes, on her fingers, lightly falling sometimes upon the brush of greenery veiling the body in its cloth. Her pale eyes are filled with tears. Tears glisten on the leaves. In the hollow, the girl is burying the body, as her tears slide down the leaves, beading the green. Tears, rolling across rocks, shiver and settle between pebbles. (25)

Her fingernails, like claws, damaged, stained, scratch at the earth, which she drops, crumbles, on top of the garlands of greenery. (26)

In the castle, whole save for the roof, she wrapped the body in her cloak and carried it and dragged it to the hollow. She placed it on the rotting floor of the sweet pine forest and covered it with leaves and earth. Her arms were strong: she carried rocks; she marked the place with rocks. She wept when she buried the body of the wolf. (26)
}

These fragments are told poetically in the timeless present of the eternal feminine, which echoes Kristeva's notion of the cyclical and silent nature of the Semantic order. Isabella never speaks; she cries and scratches at the earth. Through this instinctive representation, very closely related to female sensuality as well a grotesque representation of the body, the girl is further linked with Kristeva's pre-linguistic Semiotic, and distanced from the dominant language 
and logic of the Symbolic order. The animalization presented in these examples is both symbolic and literary. In these passages Isabella is characterized by typically feminine traits such as tears, whose artificial gender association is explored by Irigaray and Butler. Yet, this new Red Riding Hood is also shown to literally possess animalistic strength and determination as she scratches at the earth and digs with her fingernails, which are grotesquely compared to "claws." Her typically feminine sensuality is revealed through tears, which are a recurrent symbol throughout the description of the burial. They could potentially present two interpretive possibilities. In both cases they convey indescribable sadness and melancholy. In the first one Isabella cries because of the death of her lover: she has lost her true love, the one who finally allowed her to be herself and escape social norms. The ceremony in itself is important and the wolf is personified, he is loved, missed and mourned by Isabella. The other explanation is more psychoanalytical and metaphorical. Isabella cries because society has killed her wild side, deeming it unacceptable. The body of the wild beast is the symbol of the freedom which social structure deprives women of. Isabella escaped - for two years she roamed free-yet in the end she will put on her grandmother's wedding dress and ironically mourn the death of an important part of her.

Isabella did not want to leave the wolf in the castle; she wanted to give him a ceremonious burial so she acted and followed her desire. In doing this, the girl acquires some animalistic characteristics: strength and determination. Her fingernails, described as claws (26), create a monstrous image of Isabella, who embraces her wild side. This association with the primitive, along with the title of the story, brings to mind Plato's myth of the cave. On the one hand, the motif of people in chains, who are deceived by illusionary shadows, could denote a similar artificiality of the system in terms of gender politics. On the other hand, this myth is another intertextual reference which clearly subverts patriarchal reasoning and takes us back to the primitive origins of the cave. According to theories of Cohen, Braidotti, and Kristeva, the monstrous body or grotesque representation, as well as the "uncanny," break the accepted boundaries and challenge the existing system. Thus this monstrous characterization of Isabella, which opens up numerous shifting and contradicting meanings, could be interpreted as a 
subversive intent of resistance. This mixing of typically feminine traits with animal "claws" shifts the girl's identity towards a web of contradictory discourses as theorized by Braidotti in her theory of nomadic subjects.

The importance of the wolf and his personification, a technique which is indeed the opposite of animalization, is also crucial. The wolf is another marginal figure who is given a whole new characterization. The death of an animal is normally described in terms of a "carcass." At the beginning we do not know who is being buried, so we assume "the dead one" to be the lover of the girl. The wolf is no longer the wild and fierce murderer from the original fairy tale. He is the victim, "the dead one," who is loved, missed and mourned by Isabella. ${ }^{34}$ We therefore find yet another crucial distortion of the original "Little Red Riding Hood." While in Perrault's and the Grimms' fairy tale it is the grandmother and the girl who die at the end, here the wolf is dead right from the beginning of the text. From later references we can infer that the wolf the girl is burying was murdered by men. His portrayal as the marginal "other" and his association with the devil is explicit: "Two nights ago some soldiers from the north said they injured a wolf, the leader. The Devil with the fires of Hell in his eyes, they said. Maybe they got the animal. But Isabella was never found" (30). Even though the second narrator (Luis's mother) calls him "the Devil with the fires of Hell in his eyes" (Ibid.), we know she cannot be trusted.

No one can really be trusted, especially with moral judgments, because we are all shaped by society and language. In that aspect, there is an important opposition made by Luis's mother between Isabella and her grandmother. Luis's mother describes Isabella as having "the devil in her eyes" (26), thus making a harsh moral judgment and further associating the girl with monstrosity. Moreover she feels guilty for asking Isabella to do the errand and so looks for an explanation: "She went, after all, of her own free will. I was not to know. But what a fate, what a punishment! To be eaten by wolves. It's the grandmother I feel most sorry for. Because, you

\footnotetext{
${ }^{34}$ Indeed, part of the explanation for the victimization of the wolf in this story comes from his connection with Isabella, since men in the village were looking for him and eventually killed him. So, indirectly, Isabella is responsible for his death, hence the link with Mérimée's story.
} 
know, she never really knew who that girl was" (30). Not only does this highly unreliable narrator consider Isabella purely evil, but she also imitates Perrault's seventeenth-century assumption of the story ending with punishment for the disobedient girl. On the other hand, Isabella's grandmother is described as "good and respectable and proud" (26), while her house is "as clean as a convent" full of "lace... pure white" (26). This opposition could point to the hypothesis that Isabella was rebelling against her grandmother, who "swept the floor and she prayed and she made lace pillow-covers and she prayed and she prayed for a husband for her beautiful Isabella" (27). This could also be a critical approach to religion as a leading measure of morality. The appearance of traditional characters and then a twist on their fate is typical in postmodernist writing. It seems that all of the characters undergo distortion, even the grandmother, who unlike her traditional self dies of old age and of grief:

Her grandmother waited. She waited for a year for that little girl to come back. The old lady spoke to nobody but the priest. And then, one night, she died. Of grief. She died with quiet dignity, of grief. Oh, and old age, of course. (29)

The personification of the wolf as well as Isabella's animalization both help to deconstruct traditional gender roles. This distortion of social roles all forms part of the subversive intertextuality, which helps discover new meanings in seemingly familiar characters.

Through animalization Isabella is characterized as quite a distorted version of the traditional Little Red Riding Hood. Unlike the original little girl, Isabella is not meant to be representative of all young girls. Rather, she is a symbol of a marginal figure in modern society:

\footnotetext{
Isabella had a terrible reputation. She used to go up to the old castle - there is no proof - with just about anyone. Soldiers, musicians, cripples, foreigners, old men and boys. She was reasonably pretty, in a sly sort of way. Oh, but there was the devil in her eyes. Light eyes, too light for hereabouts. Black hair, light eyes - Isabella was always a strange one. Pretty enough, you know, but strange. (26)
}

My son was half in love with her - half the time. He knew it was madness. (28)

And for all that Isabella was a whore, she way really rather simple. (28) 
There are two main aspects which are highlighted in this fragment: Isabella's looks described as sly and strange, and her behavior which is criticized socially as sexually promiscuous; she is actually called "a whore." Luis's mother thinks it is "madness" that her son is attracted to in Isabella, yet she seems to attract in an instinctive way. The connotation of "sly as a fox" brings us further into the animal domain: Isabella's character is strange, secretive, wild, instinctive, and sly and cunning as an animal. She embraces her sexuality, which is described in a low, instinctive sort of way: as if she were a "rather simple" animal who would mate with "just about anyone." These fragments clearly demonstrate the instinctive sexual drive element of animalization, which could be interpreted in a positive light according to the theories of Cixous, Irigaray and Braidotti on the need for the reappropriation of the female body and sexuality. Isabella's instinctive sexuality further emphasizes the notion of silence as a strategy of resistance. Throughout the story Red Riding Hood never speaks, she is always described by others, and thus portrayed as not having control over the Symbolic system of language, yet at the same time silently rebelling against it, as she cries while burying the body of the wolf.

Isabella is not the little girl in the original story; she is said to be sly and far from a virgin:

While Isabella roamed around like a gipsy in her red-velvet cloak. Her skin was while, just touched with apricot... The granddaughter was the ripe fruit. Oh, she was a juicy apricot. (27)

This roaming free could be regarded as another animalistic trait of Isabella, although in this case there is a clear simile with the freedom of the marginal wanderer: the gipsy. The symbol of "ripe fruit" is especially important when taking into account its biblical allusion, as theorized by Kristeva. Not only is Isabella sensual, she is also transgressing all social conventions concerning giving into temptation. Isabella herself is the forbidden fruit, as she instinctively bites into sensual pleasure with delight; clearly she is a new version of biblical Eve.

The following examples from the story make key allusions to society's need to "tame" animalistic, wild instincts, such as women's sexuality. Isabella is also portrayed as a strongwilled person who does not care about society's expectations: 
None of the decent young men at the village would have much to do with her. Nobody thought she would ever find a husband. But she didn't care about that. She lived with her grandmother and she knew she would inherit the house when the old lady died. (26)

Nobody could do anything with Isabella. She always went her own way. The nuns did their best to tame her, and then they gave up and prayed for her. (27)

The old grandmother was far too weak. What Isabella needed was a father and half-a-dozen brothers to straighten her out. (27)

And that red cloak - she always wore that cloak. You could see her coming for miles. Of course, her grandmother made is for her. It would have been fine for a princess on a white horse. But there it was on Isabella as she ran from one end of the village to the other, often barefoot, meeting soldiers and travelling musicians and so on in the forest. (27)

Clearly, the postmodernist character of Isabella is much more of an individual than the nameless Little Red Riding Hood. This description of Isabella shows how she could not be forced into accepted social behavior. There is even a possible interpretation of that fact that she did not care about what people thought of her: she knew her economic status after her grandmother died would not require her to get married. She rebelled through always going her own way and being wild and free. The verb "tame" bears a special relation to wild animals which we try to domesticate in order to have power over them. The fact that the nuns unsuccessfully try to "tame" Isabella could be read as a critical approach to religion and what is socially accepted as "morally correct." Other social figures which are thought to have the role of "taming" wild behavior are the males: the father and brother figures, which represent patriarchal oppression at the level of family structure. There are recurring references to Isabella's sexual freedom, what Luis's mother called "a terrible reputation" or what we would probably call "promiscuity" or event a deviant sexuality, taking into account the cripples, old men, and boys. This sort of behavior in women would automatically lead to being labeled as whores, which does happen to Isabella throughout the story. Running barefoot is another clear example of animalization, as Isabella embraces her sensual, wild side. In the passage our new Red Riding Hood is clearly contrasted with a princess on a white horse. The comparison is blunt and leaves no doubt as to how society sees marginal figures such as Isabella, theorized as the post-colonial "other" by Said, Bhabha and Spivak. 
Throughout the story there is a new important symbol associated with the girl. This new symbol hides many subversive meanings, which reveal how Isabella embraces her wild side and defies social conventions. It is the symbol of the lace wedding dress her grandmother is making for her wedding, to which there are several references throughout the text:

\begin{abstract}
She prayed, that old woman, for a husband for Isabella. What a joke! But she did... She was making a wedding dress for Isabella. Linen and lace and the sheets and all the household linens. (27)
\end{abstract}

The wedding dress was on the bed, I believe. It was.... The finest spiderweb of lace - and white, so white. Shiny. With teardrops of crystal. A dress for the Virgin. So they put it on the statue in the convent. It seemed the only thing to do. (29)

They never found Isabella's body. If they had found it, they would have buried her in the dress. Naturally. But Isabella was never found. (30)

The girl in the tattered lace dress is burying the body. (30)

The dress is obviously a symbol of purity and of marriage. Yet it is also a symbol of the imprisonment of women in society. Every woman is expected to marry; this is the prototypical happy ending of any fairy tale. This social pressure is portrayed by the reference to the spiderweb pattern of the dress, woven beautifully in order to lure the innocent. There are also teardrops of crystal, symbolic sadness and despair, on the shiny white dress. The following sentence seems to compare a virgin with the Virgin. In a rather ironic way, it seems to state that such purity is only to be expected from Saint Mary: part of religious criticism made by many feminists. ${ }^{35}$ The next reference is rather unorthodox, yet it can easily be explained in relation to Feminism. The association of the dress and death, a burial, is a subversive message about escaping from an oppressive system. Sometimes the only way to escape is through death. Other times, marriage can equal death in the sense that the woman ceases to be an individual and becomes a wife. Etymologically woman derives from the Old English word wifman, the wife of man.

35 Julia Kristeva theorizes about the 'Biblical woman' (1986: 140). 
The last reference clarifies that the figure burying the body is in fact Isabella, wearing the wedding dress her grandmother had made for her. The dress is not pure white, it is tattered: no one is immaculate. Equally important is the fact that this detail is not given until the very end of the story, as it both reveals the identity of the girl burying the wolf and opens the door for a whole new interpretation of the burial. Not only does Isabella ironically mourn the death of an important part of her, yet we can also understand the burial in a new distorted way. This first and final scene, which makes up the frame of the story, seems to portray a heathen ritual, very much connected with nature through the use of flowers, and herbs, especially rosemary traditionally associated with faithfulness, memory and wedding celebrations. The fact that Isabella is also described as wearing the wedding dress could lead to its interpretation as a sacred vow to continue to defy the traditionally accepted social order.

The last important aspect of animalization is silence, which has always been associated with marginal beings, including women and animals. The concept of language as an instrument of control in the patriarchal system is quite significant, as opposed to the silence of many female characters. Some women rebelled against language, just as the avant-garde writers did in the first decades of the $20^{\text {th }}$ century. "El Gutural" is a short story by Estela dos Santos where a woman rebels against oppression through silence. She refuses to speak; even though she is thought to be mad, her silence is what actually keeps her sane. In "Cave Amantem" silence is also present as part of the subversive strategy of animalization.

It is important to note that Isabella never speaks in the text. Her behavior is always described, either in a sensual way by the poetic narrator or in a condescending way by Luis's mother. Even in the original fairy tale there is dialogue and the Little Red Riding Hood speaks. Isabella's silence is quite revealing, especially in the last fragment:

In the hollow between the rocks, beneath the sweet pines, in the heart of the silence of the forest, the girl is burying the body. (25)

With tears and ceremony, herbs and stones, she is burying him in the hollow. She is silent. There is a bitter smell; there is a sweet smell; he is dead. (30) 
"The heart of silence" could be interpreted to be a particularly significant echo of Conrad's Heart of Darkness. In both cases the characters are trapped in an oppressive situation, from which they long to escape. In the last excerpt Isabella is explicitly said to be silent. There are no words to describe her feelings as "the other." The silence at the end of the tale reflects the silence of marginal figures in society, as well as offers a new model of subversive resistance. There is a sensual mix of smells, which might lead us to interpret death in two distinct ways. First, death can have the traditional bitter taste of sadness, melancholy and loss, and secondly it can be seen in a different light, as a clearly positive metaphor of possible freedom from social norms and the repression of the system. This death could be interpreted as the only means of escape from a cruel society, a society that offers organic and saturated undertones. ${ }^{36}$

Together all three aspects of animalization intertwine in order to present quite a grotesque remake of the original character of Little Red Riding Hood. In portraying Isabella as a sensual, strong and determined female character who defies social rules, Carmel Bird breaks with the traditional image of the innocent child victim who is oppressed by society. The strategy of animalization constitutes an important symbolic representation of a new female reality. Through the individualistic and subversive construction of the character of Isabella the black and white world of the fairy tale is challenged and new freedom and defiance are discovered. This story does not have a blatantly surreal happy ending, as it acknowledges numerous obstacles which stand in the way of Isabella's freedom, yet it does leave us with a bitter-sweet taste of hope.

\footnotetext{
${ }^{36}$ For an elaboration of different types of communities (organic vs. unworked) and their application to Bird's fiction, see Rodríguez Salas (2012). For a more general communitarian approach to Literature in English, see the comprehensive volume edited by Martín Salván, Rodríguez Salas and Jiménez Heffernan (2013).
} 


\section{Conclusions}

Based on the analysis of the two short stories in this study, it must be concluded that the strategy of animalization constructs subversive paradigms of female sexuality and resistance through the use of familiar, fairy tale characters. In contrast with the traditional punishment of Little Red Riding Hood and her rescue by a male figure, the subversive revisions of "Little Red Riding Hood" create a much more realistic, complex world: the girl is no longer so innocent and the wolf may not be so terrible. Through the use of deconstruction these traditional associations become unravelled and new meanings freely emerge.

In their complexity Angela Carter's and Carmel Bird's tales apply to a much wider range of social, political, psychological and economic contexts. For one, the tales studied embody a purely modern problematic of female sexuality, contemplations of resistance, the search for

identity and the still-present denial of sexual instinct. Feminist theories have long debated on the best way to criticize and rebel against oppressive social systems. Angela Carter and Carmel Bird rely on the literary constructions of fantasy and fairy tale, horror and the grotesque, as well as the erotic and pornography, in order to criticize, question, and rebel through creativity.

Animalization, along with its three main components of bestiality or monstrosity, instinctive sexual drive, and silence, offers some intriguing new models. Through its association with monstrosity, it breaks with established norms and escapes easy, stereotypical classifications. It offers a world of chaos and freedom, as new possibilities emerge beyond transgressed boundaries. Through an instinctive sexual drive, which Carter referred to as "constructive pornography" (Benson, 1998: 38), this subversive literary strategy offers new ways of appropriating the female body. The strategic use of silence as resistance further questions the established social and linguistic norms. In the case of "The Company of Wolves" the animalization of Little Red Riding Hood, grounded in her grotesque representation and instinctive sexuality, is quite literal, given that it is suggested that she herself might become a werewolf. In "Cave Amantem" the monstrous descriptions of Isabella as well as what is 
perceived as her deviant sexuality contribute to a more metaphorical animalization of Red Riding Hood. In both tales the combination of monstrosity, instinctive feminine sexuality, and silence shift the girl's identity towards a web of contradictory discourses as theorized by Braidotti in her theory of nomadic subjects.

Unlike many feminist clichés destined for a specific purpose, these stories allow for a wide range of interpretative possibilities, as they dialogue with numerous traditions and genres. The authors' exploration of themes such as identity, domination, sexual desire (Gilbert, Gubar: $1985,2231)$ and entrapment is not restricted to a single interpretation, and allows the reader to explore the possibilities. This plurality of meanings echoes the original folk tales in an endless oral cycle of abundance. This concept ties in with Carter's "narrative of defamiliarization, materiality, and process" which fills the reader used to the masculine "domination and transcendence" of meaning with unease (Bacchilega, 1998: 20). The two stories analyzed are infinitely thought-provoking, moving and entertaining, but also shocking, grotesque and troubling. Unlike the visions of Perrault and Brothers Grimm, which clearly reflect social, political and religious agendas, the tales of Carter and Bird revolve around silences and marginalities, as they explore the multiplicity and ambiguity of endless post-colonial visions. The patriarchal single truth is subverted as a liberating paradigm is offered through chaos, marginality, grotesque representation, instinctive sexuality, and silence. "The beast within" is embraced, or at least accepted, as new conceptions are offered through the reference to primary instincts, as grounded in modern evolutionary psychology. The process of animalization could thus be said to contribute to "a stripping away of all existing definitions of sexuality to reach a point of shared humanity, from which men and women can separately and collaboratively build anew" (Day qtd. in Sellers, 2001: 120). It seems that in both tales the new Red Riding Hood finds greater fulfillment in the animal side of her nature. 


\section{Works Cited}

Ashcroft, B., Griffiths, G., Tiffin, H. eds. 1989. $20022^{\text {nd }}$ ed. The Empire Writes Back. London: Routledge.

Bacchilega, C. 1997. Postmodern Fairy Tales: Gender and Narrative Strategies. Philadelphia, Pennsylvania: University of Pennsylvania Press.

Bacchilega, C., Roemer, D. M. eds. 1998. Angela Carter and the Fairy Tale. Detroit: Wayne State University Press.

Baker, S. 1993. Picturing the Beast. Animals, identity and representation. Manchester: Manchester University Press.

Bakhtin, M. 1982. Estética de la creación verbal. México: Siglo Veintiuno Editores.

Barthes, R. 1968. "The Death of the Author." Literature in the Modern World: Critical Essays and Documents. Ed. Dennis Walder, trad. Stephen Heath. Oxford: Oxford University Press, 1990. 228-232.

Benson, S. 1998. "Addendum." Angela Carter and the Fairy Tale. Detroit: Wayne State University Press. 59-64.

--- 1998. "Angela Carter and the Literary Märchen: A Review Essay." Angela Carter and the Fairy Tale. Detroit: Wayne State University Press. 30-58.

Bettelheim, B. 1989. The Uses of Enchantment: The Meaning and Importance of Fairy Tales. New York: Alfred A. Knopf.

Bird, C. 1998. "Cave Amantem." The Essential Bird. Sydney: Fourth Estate. 25-30.

Braidotti, R. 1994. Nomadic Subjects: Embodiment and Sexual Difference in Contemporary Feminist Theory. New York: Columbia University Press.

Butler, J. 1990. Gender Trouble: Feminism and the Subversion of Identity. New York: Routledge.

Carter, A. 1979. "The Werewolf," "The Company of Wolves," "Wolf-Alice." The Bloody Chamber and Other Stories. London: Gollancz.

Cixous, H. 1990. "The Laugh of the Medusa." The Rhetorical Tradition: Readings from Classical Times to the Present. Cohen K. and P. trans. Boston: St. Martin's Press, Bedford Books.

Cohen, J. 1996. Monster Theory: Reading Culture. Minneapolis: University of Minnesota Press. 
Creed, B. 1993. The Monstruous-Feminine: Film, Feminism, Psychoanalysis. London and New York: Routledge.

Foucault, M. 1990. History of Sexuality Vol 1. New York: Vintage.

Gilbert, S. M., Gubar, S. 1984. The Madwoman in the attic: the woman writer and the Nineteenth-century literary imagination. New Haven: Yale University Press.

---1996 (1985). The Norton Anthology. Literature by Women. The Traditions in English. New York: Norton.

Hume, K. 1984. "Fantasy and Mimesis." Fantasy and Mimesis: Responses to Reality in Western Literature. Methuen Publishing

Irigaray, L. 1996 [1985]. "The power of discourse and the subordination of the feminine: Interview". This Sex Which is Not One. Porter, C. trans. New York: Cornell U. Press.

--- 1991. Ed. Whitford, M. The Irigaray Reader. Oxford: Blackwell.

Koch, D. M. no. 14, Otoño 2006. "Microrrelatos: Doce recursos más para hacernos sonreír." Revista electrónica: El Cuento en Red http://cuentoenred.xoc.uam.mx

Kristeva, J. 1982. "Powers of Horror: An Essay on Abjection." Trad. León S. Roudiez. New York: Columbia UP. 4.

--- 1986 (1974). “About Chinese Women”. Trans. Seán Hand. The Kristeva Reader. Ed. T. Moi. Oxford: Basil Blackwell. 138-59.

Medina, J. 2011. "Toward a Foucaultian Epistemology of Resistance: Counter-Memory, Epistemic Friction, and Guerrilla Pluralism." Foucault Studies, No. 12, 9-35.

Morris, P. 1993 (1996). Literature and Feminism: An Introduction. Oxford: Blackwell Publishers.

Noske, B. 1989. Humans and Other Animals: Beyond the Boundaries of Anthropology. London: Pluto Press. vii.

Nye, R. A. 1999. Sexuality. New York: Oxford University Press.

Palacios González, M. 2001. "Periphery as Resistance: Modernist Women Writers and the Possibilities of Transgression" in M. Barbeito, ed. Feminism, Aesthetics and Subjectivity. Essays on Women and Culture in Early Twentieth Century British Literature. Santiago de Compostela: Universidad de Santiago de Compostela. 197-206 
Pérez Gil, M. 1996. La subversión del poder en Angela Carter. Las Palmas: ULPGC.

Roberts, M. S. 2008. The Mark of the Beast: Animality and Human Oppression. West Lafayette, Indiana: Purdue University Press.

Rodríguez Salas, G. 2007. "The Boundless Ocean of Silence: An Alternative to Language in Katherine Mansfield's Doll's House." Babel A.F.I.A.L.: Aspectos de Filología Inglesa y Alemana 16: 51-64.

--- 2009. Katherine Mansfield: El posmodernismo incipiente de una modernista renegada. Madrid: Editorial Verbum.

--- 2010. “No More Lullabies For Foolish Virgins. Angela Carter and 'The Erl-King'”. English Studies (ES): Revista de Filología Inglesa 31: 223-231.

--- 2012. "A Dream-Temple of Collective Imagination: Exploring Community in Carmel Bird's Cape Grimm." Australian Literary Studies 27.1: 76-91.

Rodríguez Salas, G., Andrés-Cuevas, I.M. 2011. The Aesthetic Construction of the Female Grotesque in Katherine Mansfield and Virginia Woolf. New York: The Edwin Mellen Press.

Rose, M. A. 1993. Parody: Ancient, Modern, and Postmodern. Cambridge: Cambridge University Press.

Salván, M. et al., ed. Community in Twentieth-Century Fiction. London: Palgrave, 2013.

Sellers, S. 2001. Myth and Fairy Tale in Contemporary Women's Fiction. New York: Palgrave.

Smelik, A. 2003. "For Venus smiles not in a house of tears' Interethnic relations in European cinema." European Journal of Cultural Studies, February 2003 Vol. 6 no. 1: SAGE.

Spivak, G. C. 1981. "French Feminism in an International Frame." Yale French Studies 62.

Thomas, K. 1983. Man and the Natural World: Changing Attitudes in England 1500-1800. London: Allen Lane.

Von Franz, M. 1982 (1970). An Introduction to the Interpretation of Fairytales. Dallas, Texas: Spring Publications.

Zipes, Jack. 2012 (1983). Fairy Tales and the Art of Subversion. New York: Routledge.

--- 1993. The Trials and Tribulations of Little Red Riding Hood. New York: Routledge. 